\title{
REPORT ON THE FIRST BELT AND ROAD PHYSICAL EDUCATION FORUM
}

\author{
Zagreb, Croatia, 16-18 April 2019
}

The first Belt and Road ${ }^{1}$ Physical Education Forum was organised by the Faculty of Kinesiology, University of Zagreb with the aim that the institutions of higher education from countries included in the initiative discuss the coordinated development of sports and sport education.

In this two-day event, each institution was presented, pointing out the important facts as well as giving an overview of their activities and projects. They also proposed the possibilities of further collaboration within the $16+1$ initiative. The Science and Research Centre, Institute for Kinesiology Research was presented by the director prof. Rado Pišot, $\mathrm{PhD}$. Additionally, the meeting with the representatives of Beijing Sport University was organised where also prof. Boštjan Šimunič, PhD and Saša Pišot, $\mathrm{PhD}$ presented the possibilities of mutual collaboration on common institute's research fields.

Based on the premise of respecting the diversity of sports sciences there were 32 institutions from 16 countries that signed the consensus of promotion the development of physical education research, namely: Beijing Sport University, Beijing Normal University, Capital University of Physical Education and Sports (CUPES), Charles University, Chulalongkorn University, Comenius University in Bratislava, Gdansk University of Physical Education and Sport, German Sport University Cologne, Josef Pilsudski University of Physical Education Warshaw, Latvian Academy of Sport Education, Lithuanian Sports University, Masaryk University, National Sports Academy "Vassil Levski", Palacky University Olomouc, Russian State University of Physical Education, Sport, Youth and Tourism, Science and Research Centre Koper, Sports University of Tirana, Ss. Cyril and Methodius University in Skopje; Transylvania University of Brasov, University of Alberta, University of Belgrade, University of Ljubljana, University of Montenegro, University of Niš, University of Primorska, University of Sarajevo, University of Split, University of Tartu, University of Worcester, University of Zagreb, the University "Vasile Alecsandri" of Bacau and Western University. In this way they enabled sports to make its due contribution in promoting human health and changing human limits.

${ }^{1}$ The Belt and Road Initiative (BRI) is a global development strategy adopted by the Chinese government involving infrastructure development and investments in 152 countries and international organizations in Asia, Europe, Africa, the Middle East, and the Americas. The leader of the People's Republic of China, Xi Jinping, originally announced the strategy during official visits to Indonesia and Kazakhstan in 2013. The "Belt" refers to the overland routes for road and rail transportation, called "the Silk Road Economic Belt"; whereas the "Road" refers to the sea routes, or the 21st Century Maritime Silk Road. (available on https:// en.wikipedia.org/wiki/Belt_and_Road_Initiative). 


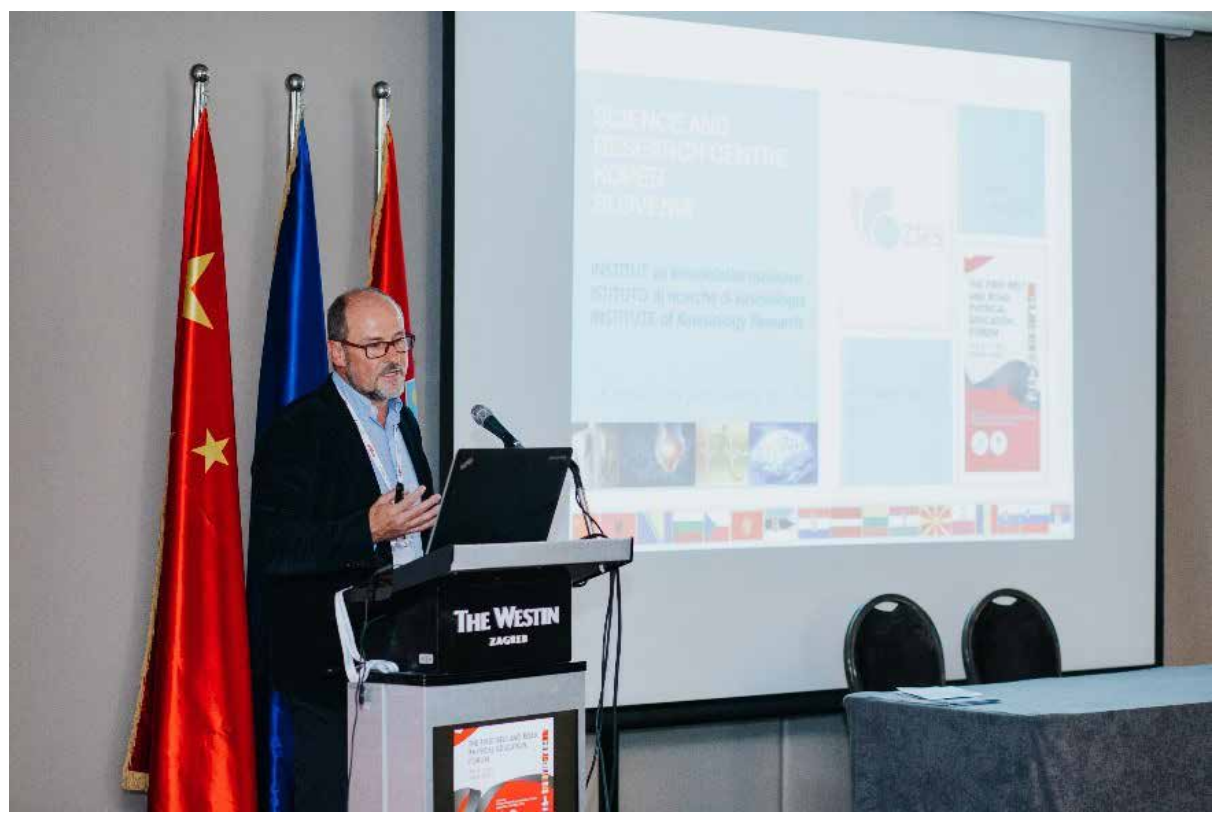

According to the consensus, the institutions are willing to jointly build a platform for collaborative research and academic exchanges, strive to improve the level of sports scientific research, and consolidate and enhance the competence of the countries along the Belt and Road in physical education research.

The first forum is certainly a welcome opportunity to open up the scientific and research potential of the Institute for Kinesiology Research of the Science and Research Centre Koper, but we will need to wait for the response from the future potential partners, so in the meanwhile we can look for similar initiatives.

Saša Pišot 


\title{
POROČILO PRVEGA FORUMA "BELT AND ROAD" ZA IZOBRAŽEVANJE V ŠPORTU
}

\author{
Zagreb, Hrvaška, 16.-18. april 2019
}

Prvi forum "Belt and Road"2 za izobraževanje v športu je organizirala Kineziološka fakulteta Univerze v Zagrebu z namenom, da visokošolskim ustanovam držav, vključenih v iniciativo, ponudi prostor za razpravo o usklajenem razvoju športa in izobraževanja v športu.

Ta dvodnevni dogodek je bil namenjen predstavitvi ustanov in podrobnejšemu pregledu njihovih dejavnosti in projektov ter prikazu možnosti nadaljnjega sodelovanja $\mathrm{v}$ okviru pobude $16+1$. Znanstveno-raziskovalno središče Koper, Inštitut za kineziološke raziskave je predstavil direktor prof. Rado Pišot. Ob tem je bilo organizirano samostojno srečanje s predstavniki Pekinške univerze za šport, kjer sta možnosti za razvoj sodelovanja na skupnih področjih predstavila prof. Boštjan Šimunič in dr. Saša Pišot.

Skladno s spoštovanjem raznolikosti znanosti o športih je 32 ustanov iz 16 držav (Pekinška univerza za šport, Pekinška Normal univerza, Kapital univerza za telesno vzgojo in šport (CUPES), Karlova univerza v Pragi, Univerza Chulalongkorn, Univerza Comenius v Bratislavi, Univerza za telesno vzgojo in šport v Gdansku, Nemška univerza za šport v Kölnu, Univerza "Josefa Pilsudskega“ za telesno vzgojo v Varšavi, Latvijska akademija za športno vzgojo, Litovska univerza za šport, Masarykova univerza v Brnu, Nacionalna športna akademija „Vassil Levski“ v Sofiji, Univerza Palacky Olomouc, Ruska državna univerza za telesno vzgojo, šport, mladino in turizem, Znanstveno-raziskovalno središče Koper, Univerza za šport v Tirani, Uuniverza Cirila in Metoda v Skopju, Transilvanska Univerza v Brasovu, Univerza v Alberti, Univerza v Beogradu, Univerza v Ljubljani, Univerza v Črni Gori, Univerza v Nišu, Univerza na Primorskem, Univerza v Sarajevu, Univerza v Splitu, Univerza Tartu, Univerza iz Worcestra, Univerza v Zagrebu, Univerza „Vasile Alecsandri“ v Bacauu in Univerza Western) podpisalo soglasno izjavo za promocijo razvoja raziskovanja športa in telesne vzgoje, s katero želijo omogočiti, da šport v svoji vlogi še nadalje ustrezno prispeva k promociji zdravja ljudi in premikanju človeških omejitev.

Glede na podpisano izjavo so institucije podpisnice pripravljene graditi platformo za skupne raziskave in akademske izmenjave, si prizadevati za izboljšanje ravni znanstvenih raziskav s področja športa ter utrditi in povečati usposobljenost držav ob »Belt and Road« pri raziskovanju telesne vzgoje.

${ }^{2}$ Pobuda Belt and Road (BRI) je globalna razvojna strategija, ki jo je sprejela kitajska vlada in vključuje razvoj infrastrukture in naložbe v 152 držav in mednarodnih organizacij v Aziji, Evropi, Afriki, na Bližnjem vzhodu in v Ameriki. Vodja Ljudske republike Kitajske Xi Jinping je strategijo prvotno napovedal med uradnimi obiski Indonezije in Kazahstana leta 2013. „The Silk Road Economic belt“" se nanaša na kopenske poti (cestni in železniški promet) - „Belt“, medtem ko se „Road“ nanaša na morske poti ali pomorsko svileno pot 21. stoletja. (dostopno na https://en.wikipedia.org/wiki/Belt_and_Road_Initiative). 


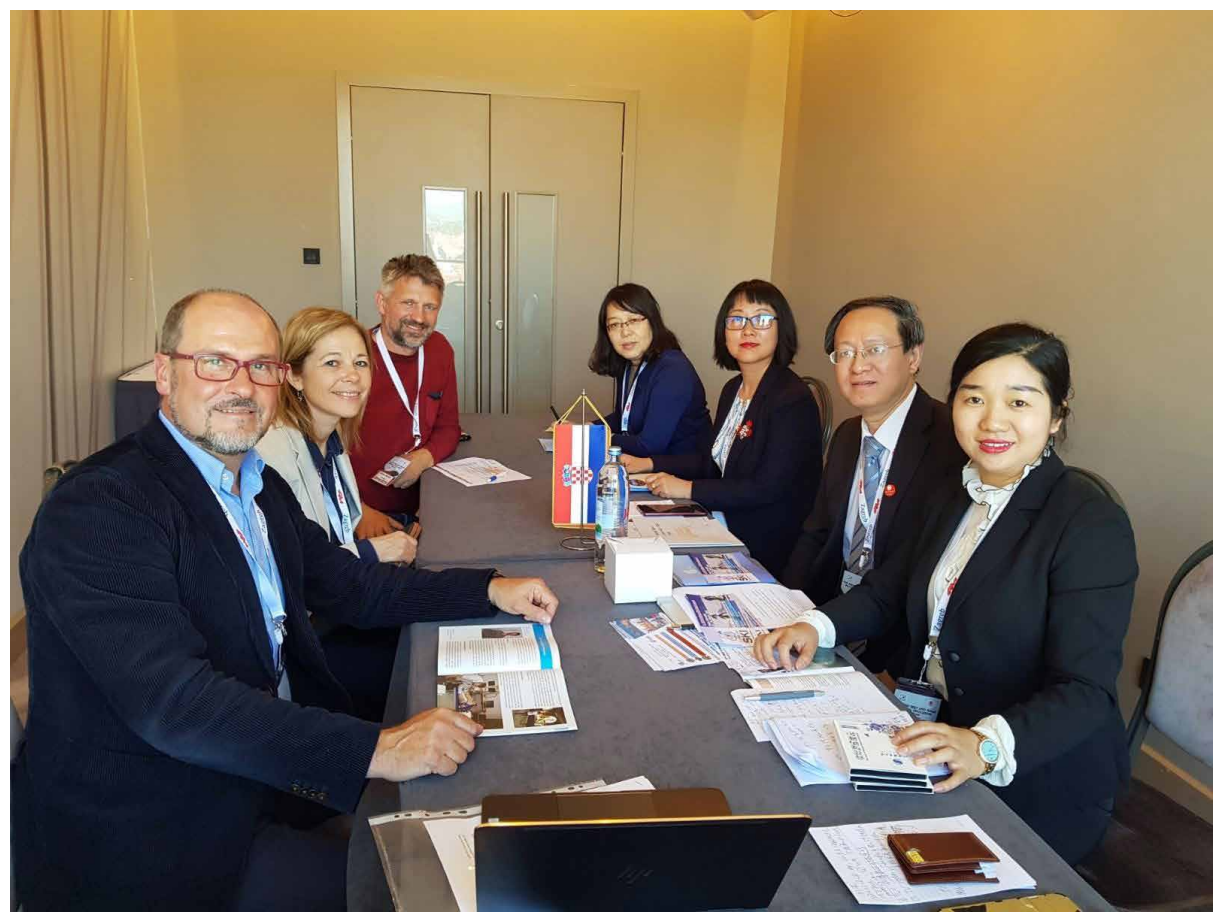

Prvi forum je bil zagotovo dobrodošla možnost in odskočna deska za nadaljnje odpiranje raziskovalnih potencialov Inštituta za kineziološke raziskave ZRS Koper, seveda pa bo potrebno počakati na odziv bodočih potencialnih partnerjev in hkrati iskati podobne pobude.

Saša Pišot 